\title{
SCHUMPETERIAN \\ ASPECTS OF GROWTH \\ AND ITS CORRELATIVE CLASSICAL AND NEOCLASSICAL APPROACHES
}

\author{
SERGIO A. BERUMEN ${ }^{1 *}$
}

Fecha de recepción: 15 de marzo de 2015

Fecha de aceptación: 13 de septiembre de 2015

\begin{abstract}
Economic Growth is a central concept in Economic Theory. Most of the modern societies regard growth as an important determinant for rising standards of living. Their effects can be observed not only in more goods and services but also in brand new processes. Investment in human capital is regarded as the very source of long-term, sustainable Economic Growth. The purpose of this paper is to provide a brief description of Economic Growth, how to approach its measurement, and to provide a brief review of the Schumpeterian thought and the main schools that have undertaken from the Classical and Neoclassical Approaches.
\end{abstract}

Key Words: Economic Growth; Schumpeterian Thought; Classical and Neoclassical Approaches.

JEL Classification: B12, B13, B52, O43, 049.

Título: Schumpeter, el crecimiento económico y los enfoques clásico y neoclásico.

Resumen: El crecimiento económico es un concepto fundamental de la teoría económica. La mayoría de las sociedades modernas consideran el crecimiento como una determinante importante para el incremento de los niveles de vida. Sus efectos se pueden observar en el aumento de bienes y servicios, pero también en la disponibilidad de nuevos procesos. En este escenario, la inversión en capital humano es, de hecho, la fuente original del crecimiento econó-

\footnotetext{
${ }^{1}$ Department of Applied Economics I. King Juan Carlos University (Spain). E-mail: sergio.berumen@urjc.es
} 
mico a largo plazo y de manera sostenible. El objetivo del presente trabajo consiste en explorar los principales rudimentos del crecimiento económico, de su preceptiva medición y de mostrar las aportaciones originales alcanzadas desde el Pensamiento Schumpeteriano, así como de su contrastación con las perspectivas Clásicas y Neoclásicas.

Palabras clave: Crecimiento económico; Pensamiento Schumpeteriano; aproximaciones Clásica y Neoclásica.

\section{I \\ INTRODUCTION}

Economic Growth, defined hereinafter as the increase in a nation's Gross Domestic Product (GDP), is a fundamental issue in economics. It helps us to measure a country's economic achievements in a period, or its ability to increase output in the long-run ${ }^{2}$. In the twentieth century, Economic Growth was clearly perceived by many western nations through the thirty-year long sustained growth experienced at the end of the Second World War (von Mises, 1944; Aghion and Howitt, 1998; Scherer, 1999). However, economic theory was relatively unfit to offer a reasonable explanation for such a phenomenon. For example, economists at that time tended to explain growth through simple quantitative changes operated in the ratio of capital and labor (Stern, 1991; Hülsmann, 1999).

Although this approach was commonly accepted in academic circles, some scholars began to show signs of discomfort especially in relation to the differential rates of growth that were observed between industrialized and industrializing countries (Hoselitz, 1952; Hahn and Matthews, 1964). And then in 1986 Paul Romer set up the basis for a new approach by paying a closer attention to the role played by more qualitative factors such as knowledge (Verspagen, 2005). Romer has looked at the impact of cumulative technological capabilities (i.e., human capital) on productivity and growth,

${ }^{2}$ This definition is akin to those existing in many economic textbooks such as Mankiw (2002), Parkin (2003) and Samuelson and Nordhaus (2002). 
realizing that technical change (Hoselitz, 1963) was not as exogenous as formerly believed but it stems endogenously from growth itself (Fagerberg, 1994: 1170).

In this context, the purpose of this paper is to introduce the main theoretical concepts that define the economics of innovation, knowledge, and growth. It seeks to serve as a preliminary guide to this important process. The article is structured in four sections. The first section discusses the theoretical aspects of Economic Growth. The following section presents some indicators used to measure knowledge's impact on the economy. The third section analyzes the principal schools of thought in Economic Growth, namely, the classic approach, the neoclassic school and the Schumpeterian thought (Berumen, 2008). This work finishes with a brief summary of the concepts that were presented.

II

\section{ECONOMIC GROWTH: THEORETICAL ASPECTS}

Jovanovic (2001) points out three main causes in economic theory that explain growth in standards of living: (a) the progress of science and productive knowledge; (b) the growth of individual skills; and (c) incentives. In relation to these causes, Scherer (1999) and Verspagen (2005) argue that productive knowledge is increasingly seen as one of the main factors behind Economic Growth, which is materialized through better production techniques, more efficient processes, and the use of cheaper inputs and methods, all of which help to create new (or substantially improved) products and services. Many studies in the field of innovation and technical change has produced very detailed analyses regarding the way in which knowledge determines innovation, and especially in relation to the effect of learning on innovation (Berumen and Merritt, 2010) ${ }^{3}$. Kenneth Arrow (1962), for example, argues that gross investment in capital goods benefits from the cumulated improvements in labor's quality, which stems from day-to-day learning during production. Arrow names this process as «learning by doing».

${ }^{3}$ See, for example, the classical works of Kaldor (1957) and Arrow (1962). 
Arrow was among the first scholars who identify this kind of externalities in production (Hall, 1994). These externalities, which are called knowledge spillovers, appear from the continuous interplay between physical investments in machines and equipment and workers' knowledge. That is, firms producing capital goods learn at the same time as they manufacture new equipment, businesses investing in this equipment learn by using it - though firms not currently investing in this capital can also learn from the experience of others- and all this new knowledge becomes itself an input for the economy as a whole.

Hall (1994: 327) points out that this process enhances the effectiveness of physical inputs globally - and because the effectiveness of the inputs is enhanced at the same time as the aggregate capital stock increases - a given increase of all inputs can yield a more than proportional increase of the aggregate output, that is, there appear increasing returns at the macro-level. Another way in which knowledge is converted into innovations is through the processes of creativity, appropriability, and diffusion of skills and abilities that help to solve technical and economic problems. In the specialized literature on technical change a knowledge-based economy is defined as one in which growth is dependent on the creation, diffusion and use of knowledge (Heng, et al., 2002; Verspagen, 2005).

For the Organization for Economic Cooperation and Development (OECD) «a knowledge-based economy is defined as one where knowledge (codified ${ }^{4}$ and tacit ${ }^{5}$ ) is created, acquired, transmitted and used more effectively by enterprises, organizations, individuals and communities for greater economic and social development» (OECD, 2000a: 13). On the other hand, Rogers (2001) argues that innovation must be seen as a social process in which

\footnotetext{
${ }^{4}$ Tacit knowledge is that one which is not expressed by codes (i.e., codified) because is produced by experience, observation and routines, and is normally embedded in workers moving from one firm to other (see, Grimaldi and Torrisi, 2001; Nonaka and Takeuchi, 1995). This is the type of knowledge to which Kenneth Arrow refers to in his model (Arrow, 1962).

${ }^{5}$ Codified knowledge is that one which is expressed in a formal, explicit and uniform manner, and for this reason it is possible to put into the form of patents, books, papers, etc. (ibid).
} 
the joint participation of so many economic agents with different productive skills and intellectual capabilities determine the process' success. Since a commercial perspective, Low and Abrahamson (1997) also agree in pointing out that human skills are an essential component of innovation.

For Nonaka and Takeuchi (1995) in order for learning and knowledge to be effective it is necessary that the mechanisms of acquisition of information, comprehension, and skills be efficient. Yet, an absence of effective skills among workers is still capable of having damaging effects in a knowledge-based economy because an insufficient (or very low) level of technological capabilities can hamper growth because the implementation of new ideas asks for a minimum level of skills and resources from productive agents, as Jovanovic argues:

$\{\ldots\}$ to put new ideas into practice requires resources and skill. True, some technologies are so user friendly that their use demands no skill at all; to use a light bulb, for instance, all you have to do is screw it in. But you cannot do much with a computer if you have no education and no experience with computers (Jovanovic, 2001: 4099).

In practice the acquisition of productive skills needs a formal training process and a solid education background, with education being the most important factor for the success of those economies willing to be based on knowledge (World Bank, 1998; OECD, 1996; 1998). The role played by education in a knowledge-based economy has been stressed in the literature on national systems of innovation ${ }^{6}$. Under the context of a national system, education is seen as a crucial platform to support the innovative capabilities of a country (Lundvall, 1992; Nelson, 1993).

Although education is an important component of a national system of innovation, the institutional milieu is also crucial to support the innovative capabilities of that system. In this perspective a

${ }^{6}$ According to Mowery and Oxley (1997: 154), national innovation systems can be understood as the network of public and private institutions within an economy that fund and perform R\&D, translate the results of $R \& D$ into commercial innovations and effect the diffusion of new technologies. 
functional institutional framework tends to facilitate the transformation of knowledge into commercial innovations. For example, the instrumentation of public policies to promote industrial innovation has better chances of succeeding when the institutional context is functional, all of which improve the effectiveness cumulative social knowledge (Rodrik, 2007).

Nations can use a number of fiscal policies such as employment incentives, industrial subsidies and regulatory rules and norms to set up, at a macroeconomic level, the appropriate conditions that help to spur innovation through knowledge-intensive investments ${ }^{7}$ (OECD, 2007). In relation to the instrumentation of this type of policies, a small group of countries in the OECD area stands up because of their successful application of plans and programs focused on promoting knowledge and innovation. These nations are Sweden, Finland, Japan, Switzerland, South Korea, the United States and Germany. The key for their success in promoting innovation-led growth has been their persistent and increasing investment, as percent of GDP, in research and development (R\&D). That is, the amount of money spent by these nations on $R \& D$ during the last decade exceeds the average percent of the OECD area, as the following figure shows.

TABLE 1

GROSS EXPENDITURES ON R\&D (AS \% OF GDP)

FOR SELECTED OECD MEMBERS: 2004-2011

\begin{tabular}{|c|c|c|c|c|c|c|c|c|}
\hline & 2004 & 2005 & 2006 & 2007 & 2008 & 2009 & 2010 & 2011 \\
\hline Australia & 1,73 & -- & 2,01 & -- & 2,26 & -- & $2,20^{c}$ & -- \\
\hline Austria & 2,24 & $2,46^{c}$ & 2,44 & 2,51 & $2,67^{c}$ & 2,71 & $2,79^{c}$ & $2,75^{\mathrm{c}}$ \\
\hline Belgium & 1,86 & 1,83 & 1,86 & 1,89 & 1,97 & 2,03 & 2,00 & $2,04^{\mathrm{p}}$ \\
\hline Canada & 2,07 & 2,04 & 2,00 & 1,96 & 1,92 & 1,94 & 1,85 & $1,74^{\mathrm{p}}$ \\
\hline
\end{tabular}

${ }^{7}$ Khan (2001: 22) defines investment in knowledge as expenditures directed towards activities with the aim of enhancing existing knowledge and/or acquiring new knowledge or diffusing knowledge. According to Khan, education and software expenditures, training, innovation and industrial design expenditures should also be additional components of the total investment in knowledge. 


\begin{tabular}{|c|c|c|c|c|c|c|c|c|}
\hline Chile & -- & -- & -- & 0,31 & 0,37 & 0,41 & 0,42 & -- \\
\hline $\begin{array}{c}\text { Czech } \\
\text { Republic }\end{array}$ & 1,20 & 1,35 & 1,49 & 1,48 & 1,41 & 1,47 & 1,55 & 1,84 \\
\hline Denmark & 2,48 & 2,46 & 2,48 & 2,58 & 2,85 & 3,16 & 3,07 & $3,09^{c p}$ \\
\hline Estonia & 0,85 & 0,93 & 1,13 & 1,08 & 1,28 & 1,43 & 1,63 & $1,38^{\mathrm{p}}$ \\
\hline Finland & 3,45 & 3,48 & 3,48 & 3,47 & 3,70 & 3,94 & 3,90 & 3,78 \\
\hline France & 2,16 & 2,11 & 2,11 & 2,08 & 2,12 & 2,27 & 2,24 & 2,25 \\
\hline Germany & 2,50 & 2,51 & 2,54 & 2,53 & 2,69 & 2,82 & 2,80 & 2,84 \\
\hline Greece & $0,56^{c}$ & 0,60 & $0,59^{c}$ & $0,60^{c}$ & -- & -- & -- & -- \\
\hline Hungary & 0,88 & 0,94 & 1,01 & 0,98 & 1,00 & 1,17 & 1,17 & 1,21 \\
\hline Iceland & -- & 2,77 & 2,99 & 2,68 & $2,65^{p}$ & -- & -- & -- \\
\hline Ireland & 1,23 & 1,25 & 1,25 & 1,29 & 1,46 & $1,76^{\mathrm{c}}$ & $1,71^{\mathrm{c}}$ & $1,72^{\mathrm{cp}}$ \\
\hline Israel $^{1}$ & 4,29 & 4,43 & 4,51 & 4,86 & 4,77 & 4,49 & 4,34 & 4,38 \\
\hline Italy & 1,09 & 1,09 & 1,13 & 1,17 & 1,21 & 1,26 & 1,26 & $1,25^{p}$ \\
\hline Japan & 3,13 & 3,31 & 3,41 & 3,46 & 3,47 & 3,36 & 3,26 & -- \\
\hline Korea & 2,68 & 2,79 & 3,01 & 3,21 & 3,36 & 3,56 & 3,74 & -- \\
\hline Luxembourg & 1,63 & 1,56 & 1,66 & $1,58^{c}$ & 1,66 & 1,72 & 1,48 & $1,43^{\mathrm{cp}}$ \\
\hline Mexico & 0,40 & 0,41 & 0,38 & 0,37 & 0,41 & 0,44 & -- & -- \\
\hline Netherlands & 1,93 & 1,90 & 1,88 & 1,81 & 1,77 & 1,82 & 1,85 & $2,04^{\mathrm{p}}$ \\
\hline $\begin{array}{c}\text { New } \\
\text { Zealand }\end{array}$ & -- & 1,14 & -- & 1,19 & -- & 1,30 & -- & -- \\
\hline Norway & 1,57 & 1,51 & 1,48 & 1,59 & 1,58 & 1,76 & 1,68 & $1,64^{\mathrm{P}}$ \\
\hline Poland & 0,56 & 0,57 & 0,56 & 0,57 & 0,60 & 0,67 & 0,74 & 0,77 \\
\hline Portugal & $0,74^{c}$ & 0,78 & $0,99^{c}$ & 1,17 & 1,50 & 1,64 & 1,59 & $1,49^{p}$ \\
\hline $\begin{array}{c}\text { Slovak } \\
\text { Republic }\end{array}$ & 0,51 & 0,51 & 0,49 & 0,46 & 0,47 & 0,48 & 0,63 & 0,68 \\
\hline Slovenia & 1,39 & 1,44 & 1,56 & 1,45 & 1,66 & 1,85 & 2,09 & $2,47^{p}$ \\
\hline Spain & 1,06 & 1,12 & 1,20 & 1,27 & 1,35 & 1,39 & 1,39 & 1,33 \\
\hline Sweden & 3,58 & 3,56 & 3,68 & 3,40 & $3,70^{c}$ & 3,60 & $3,39^{c}$ & $3,37^{c}$ \\
\hline Switzerland & 2,82 & -- & -- & -- & 2,87 & -- & -- & -- \\
\hline Turkey & 0,52 & 0,59 & 0,58 & 0,72 & 0,73 & 0,85 & 0,84 & -- \\
\hline $\begin{array}{l}\text { United } \\
\text { Kingdom }\end{array}$ & 1,69 & 1,72 & 1,74 & 1,77 & $1,78^{c}$ & $1,84^{\mathrm{c}}$ & $1,80^{c}$ & $1,77^{\mathrm{p}}$ \\
\hline $\begin{array}{l}\text { United } \\
\text { States }\end{array}$ & 2,55 & 2,59 & 2,65 & 2,72 & 2,86 & 2,91 & 2,83 & $2,77^{p}$ \\
\hline
\end{tabular}




\begin{tabular}{|c|c|c|c|c|c|c|c|c|}
\hline EU27 & 1,73 & 1,74 & 1,76 & 1,77 & 1,84 & 1,92 & 1,91 & $1,94^{\mathrm{p}}$ \\
\hline $\begin{array}{c}\text { OECD } \\
\text { Total }\end{array}$ & 2,18 & 2,22 & 2,26 & 2,29 & 2,36 & 2,41 & 2,38 & -- \\
\hline
\end{tabular}

Source: Main Science and Technology Indicators, OECD Science, Technology and R\&D Statistics

Note: Country specific footnotes are available at http://www.oecd.org/sti/ msti_2012_2_documentation_e.pdf

1. The statistical data for Israel are supplied by and under the responsibility of the relevant Israeli authorities. The use of such data by the OECD is without prejudice to the status of the Golan Heights, East Jerusalem and Israeli settlements in the West Bank under the terms of international law.

c) National estimate or projection

p) Provisional

It is worth mentioning that the current Economic Growth of some OECD members (namely Finland, South Korea and Sweden) is being increasingly supported by sustained investments in Information and Communication Technologies (ICTs). As pointed out by Shapiro and Varian (1999), ICTs are actually facilitating and accelerating the adoption and diffusion of the accumulated knowledge.

According to Luc Soete (2001: 26-27), ICTs represent the first global technological transformation with which modern societies have been confronted. In his opinion, ICTs' impact on globalization lands in five lines of development: 1) in finance because capital is the ultimate (intangible) global tradeable good; 2 ) in the farranging deregulation move leading not only to the liberalization of trade and investment flows but also to the deregulation of many intermediate services which are central in the organization of markets and transactions; 3 ) in the practice of formalized (and publicly announced) international co-operation and agreements between firms; 4 ) in the free exchange of information and knowledge about new products and markets, that is conveyed by academic activities and media; and 5) in the stock of expertise, experiences, and personal networks that have developed over years in international relations and business, mainly through the activities of internationalized business services but also through personal contact and cultural links.

The impact of ICTs on a knowledge-based economy is larger when new products and services such as the Internet and the mo- 
bile telephony are considered. Interestingly, these technologies were themselves a result of knowledge-intensive processes. Therefore, it is necessary to evaluate the role played by technological infrastructure on innovation (Tassey, 2004); or as Shapiro and Varian has pointed out, «infrastructure is to information as a bottle is to wine: the technology is the packing that allows the information to be delivered to end consumers» (Shapiro and Varian, 1999: 8).

From an enterprise's viewpoint, Economic Growth and development in an ICT age will be determined by increasing levels of interrelation and interconnection with cumulative knowledge being the key factor to survive. In a following section we will discuss how economic theory formally describes the process of knowledge accumulation. In the meantime we will present some indicators that will be useful in measuring the economics of innovation and knowledge.

III

SOME INDICATORS FOR THE KNOWLEDGE-BASED ECONOMY

Traditionally, the measurement of knowledge has been a nuisance for the economic modeling of innovation because of the difficulties in handling the term «knowledge». In this respect, Kenneth Boulding (1966) regrets to acknowledge that there is a lack of an appropriate word to describe mind's content without having to discuss whether this content actually relates closely to the mind's structure. Given the difficulties in establishing a cardinal measurement of «knowledge», most existing economic models use proxy indicators to that $\mathrm{end}^{8}$. These indicators generally group around four main categories ${ }^{9}$ :

\footnotetext{
${ }^{8}$ Ian Steedman has critically reviewed the theoretical treatment of knowledge in those models pertaining to the so-called «New Growth Theory» (NGT). For him, there is a faulty assumption in thinking of the stock of knowledge as homogenous, which, he argues, may well not be cardinally measurable; so that these models cannot yield convincing conclusions (Steedman, 2001: 10).

${ }^{9}$ A useful taxonomy in this field has been provided by Heng and colleagues (2002).
} 
(1) Knowledge Creation, which can be approached by: 1.1) the percentage of GDP spent on R\&D, (i.e., the intensity of R\&D conducted in the economy); 1.2) the number of researchers per capita, (i.e., the availability of human resources needed for R\&D); and 1.3) the number of U.S. patents per capita, (i.e., the overall quality of the national innovation system by the scientific output it creates).

(2) Knowledge Acquisition/Transfer, which can be approached by: 2.1) the percentage of total imports that goes to technology balance of payments (i.e., the intellectual content embedded in imports from other countries); 2.2) The number of head and regional offices in a country, (i.e., the amount of firm-specific knowledge brought in by Multinationals and regional firms); and 2.3 ) The size of the knowledge intensive business services sector, (to provide intermediate products and services to firms, thereby perpetuating innovative practices and services from global sources).

(3) Knowledge Diffusion, which can be approached by: 3.1) ICT spending as a percentage of GDP, (i.e., the intensity of resources put into developing information infrastructure); 3.2) Internet access cost as a percentage of per capita GDP, (i.e., the affordability of ICT services, which will determine the usage of a country's ICT network); and 3.3) The percentage of workforce with at least secondary school education, (i.e., the basic IT and linguistic skills to tap onto ICT network).

(4) Knowledge Application, which can be approached by: 4.1) The percentage of workforce with university education, (i.e., the ability of workforce to seek out, process and use relevant information); 4.2) The percentage of «knowledge workers» in workforce, (i.e., jobs that demand and allow workers to apply knowledge extensively); 4.3) The World Competitiveness Yearbook ranking of entrepreneurship, (i.e., the ability of the economy to create new business models for generating, acquiring, diffusing and applying new ideas and processes).

It is worth stressing that this kind of indicators is becoming a standard in OECD evaluations of innovation capabilities within a national system (see, for example, OECD, 2006). Therefore, the use 
of indicators allows the comparison of innovative performance between countries and the true contribution of knowledge-intensive sectors to Economic Growth in a given nation. This aspect of growth is important in evaluating the degree of acquisition of knowledge and skills in a knowledge-based economy (see, for example, OECD, 1996; 1998; 2000b; 2007). Once we have seen the importance of measuring knowledge, we now shall discuss the main theoretical approaches that support the empirical analysis of Economic Growth.

IV

THE CLASSICAL APPROACH TO TECHNICAL CHANGE

The first formal approach to the analysis of Economic Growth was advanced just in the beginnings of the industrial revolution at the end of the eighteenth century in England (Stern, 1991). In that time England was experiencing a demographic boom as a result of unprecedented improvements in people's welfare ${ }^{10}$. Nonetheless, the effects of this population explosion did not take long to alarm perceptive observers, especially to Thomas Robert Malthus.

Malthus became famous due to their dismal thoughts on the economic consequences of the British overpopulation. In order for him to support his hypotheses, Malthus had to peer painstakingly at statistics on births and deaths available in English churches. By doing this, Malthus set up the basis of statistical analysis in economics. Malthus' work in population statistics led him to formulate the first-ever theory of Economic Growth (Scherer, 1999: 10-16).

The synthesis of the Malthusian vision of Economic Growth is as follows. For Malthus Economic Growth (Y) is determined by the quantity of workers engaged in production (L), which, in

${ }^{10}$ Parkin reports that after being relatively stable for several centuries, the population of Britain increased by 40 percent between 1750 and 1800 and by a further 50 percent between 1800 and 1830. Parkin attributes this population expansion to improvements in diet and hygiene (Parkin, 2003: 557). 
turn, depends on population (N). That is, Economic Growth is a function of the size of population and the capital involved ${ }^{11}$, as the following equation suggests:

$$
Y=f(\bar{K}, L(N)
$$

In this approach, an increase in population $(\mathrm{N})$ lowers workers' productivity because the capital stock is fixed $(\bar{K})$. A peculiar feature of this model is that it assumes that population will grow exponentially if it is not fettered, while food and meals will show a slower growth rate (Malthus, 1803[1999]). Formally the equation that explains the population growth rate in the Malthusian scheme is:

$$
N(t)=N_{0} e^{r t}
$$

Under a population explosion trend, wages tend to decline and thus becoming insufficient to guarantee life. In that case workers cannot survive. This situation triggers a population-cut mechanism which tends to steer the economic system back to the original equilibrating point.

This process is better explained in the following figure, which shows how the growth process begins at point $\mathrm{A}$, where the economy is in equilibrium. In this point the productivity curve $\left(\mathrm{CP}_{1}\right)$ intersects the subsistence wage. In this scheme technical change is modeled as an exogenous event which translates the productivity curve toward an upper value $\left(\mathrm{CP}_{2}\right)$, moving the economy up to a new equilibrium (point $B$ ). As a result, population grows and both capital and real GDP per hour tend to diminish. The process finishes at point $C$ when real GDP per hour returns to its former subsistence level.

${ }^{11}$ The logic of this situation rests on the fact that workers had to get a subsistence real wage as large as to keep them alive, but in case it was not large enough as to maintain life they clearly had no incentives to work for any patron offering such a low wage (Costabile and Rowthorn, 1985). 
FIGURE 1

CLASSICAL GROWTH MODEL

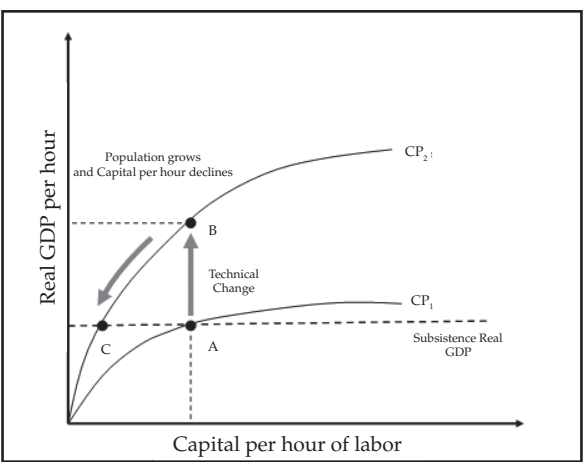

According to the abovementioned figure, if productivity were enhanced by an unexpected innovation, workers would suffer in the long-term because enhanced productivity would stimulate people to fathering more children, and thus increasing total workforce. So, wages would have to plummet as a consequence of overpopulation. In this point, new wages would be insufficient to guarantee the new workers' subsistence pushing the unemployed workforce to starving, cutting down the excess in population, and thus returning wages to the former equilibrium level. This is Malthus' model in a nutshell.

Needless to say that Malthus' dismal forecast has never materialized because he (wrongly) assumed that population grows unfettered when real GDP per hour exceeds workers' subsistence wages ${ }^{12}$. Yet, this theoretical mistake took years to overcome and Economic Growth was not satisfactorily explained until a more comprehensive understanding of the economic forces determining productivity growth was available, as seen next.

${ }^{12}$ For a more detailed discussion on the Classical model, see Scherer, 1999, pp. 8-16. 
Due to the rapid recovery of the world economy in the aftermath of the Second World War, Economic Growth began to capture the attention of academic circles (Amable, 1994). Although the explanations to the phenomenon existing at that time were suitable to explicate the trajectories shown by the post-war economies, they began to exhibit various theoretical and interpretative deficiencies. Consequently, a change in the theoretical approach to Economic Growth emerged in the mid-1950s: the Neoclassical approach (Mankiw, 2002).

The Neoclassical School of Economic Growth follows the Classical perspective on production by considering labor and capital (the traditional inputs in production) prone to exhibit decreasing returns if used in isolation from each other, but it represents a reassessment of the Classical Theory by proposing that GDP per capita tends to grow when technical change induces new investment and saving rates which, in turn, tend to raise capital per hour of labor. This approach is known as the theory of balanced growth, or steady-state growth (Hall, 1994; Scherer, 1999).

Even though Roy Harrod and Evsey Domar are acknowledged as the pioneering contributors of this approach, the analyses produced by Frank Ramsey in the mid-1920s in Cambridge can be seen as the true origin of the Neoclassical Theory of Economic Growth (Aghion and Howitt, 1998).

The Neoclassical theory of Economic Growth assumes that capital $(\mathrm{K})$ is cumulative whereas labor (L) may or may not be so. This implies that without an upward trend in the use of input $\mathrm{L}$ - or under a constant pace of technical change - growth will sooner or later come to a halt due to decreasing returns in the use of $\mathrm{K}$, which is the only cumulative input (Hall, 1994).

However, Economic Growth based only on capital accumulation tends to provoke a declining rate of return which cancels out any long-term incentive to invest. Under these conditions, only exogenous factors may spur growth (Scherer, 1999; Verspagen, 2005). Given that growth depends crucially on technical change in the Neoclassical perspective, it is then possible to distinguish two 
types of modeling in this school: those models in which all technological activity is exogenous to the system, and those in which technical change is actually endogenous. We shall discuss the first type first.

\section{VI \\ NEOCLASSIC MODELS OF EXOGENOUS GROWTH}

The neoclassic approach assumes a well-behaved and simplified production function (i.e., homogenous of degree 1 with decreasing returns for each input). Under these assumptions, output per worker $(\mathrm{Q} / \mathrm{L})$ will tend to zero in case of lack of innovations (Gregersen and Johnson, 2000). The most prominent exemplar of the neoclassic model of exogenous growth is Robert Solow's (1956; 1957). For Solow, capital accumulation alone (without technical progress) tends to reduce future returns on capital, and thus curbing the incentives of long-term investment. In such a case, investment will barely cover fixed capital depreciation and the necessary equipment for day-to-day operations. We shall now describe this model in more detail.

According to Gregersen and Johnson (2000), labor (L) and technical progress (A) grow at a constant exogenous rate. All savings resulting are invested, and output $(\mathrm{Q})$ is dependent on labor (L) and capital (K). Moreover, the involved production function exhibits constant returns to scale in total output but decreasing returns in individual inputs. The equation describing this situation is:

$$
Q=A K^{\alpha} L^{\beta}, \quad(\alpha+\beta=1)
$$

Transforming this equation into its logarithmic form and deriving it with respect to time, we will have the following expression $^{13}$ :

${ }^{13}$ In Solow's equation, $\alpha$ and $\beta$ are the inputs' shares in total output and constant returns to scale are present when these shares add up to one (see, Gregersen and Johnson, 2000; Scherer, 1999). 


$$
\frac{\dot{A}}{A}=\frac{Q}{Q}-\left[\alpha \frac{\dot{K}}{K}+(1-\alpha) \frac{L}{L}\right]
$$

In the equation shown above, $\AA / A$ is the residual's rate of growth, $\alpha$ is the capital's share in total output (Q) and $\dot{K}_{K}, \dot{L} / L$ represents the rate of growth in either variable $\mathrm{K}$ or $\mathrm{L}$ across time. On the other hand, $\AA$ /A involves a measure of technical progress (as in Solow's model); so, it becomes necessary to know what part of that change (which corresponds to an increase in productivity) is explained by $\mathrm{K}$ and what part is explained by L. It is worth pointing out that Solow defines all changes in output attributable to capital as a level effect, whereas changes attributable to labor are defined by Solow as growth effects (Solow, 1957: 319). These conditions are shown in the following equation, which is a rearrangement of the previous one.

$$
\frac{\dot{A}}{A}=\alpha\left[\frac{\dot{Q}}{Q}-\frac{\dot{K}}{K}\right]+(1-\alpha)\left[\frac{\dot{Q}}{Q}-\frac{\dot{L}}{L}\right]
$$

According to Solow, level effects are determined either by increases (or cuts) in the propensity to save, or by increases in capital caused by agents' investments. Growth effects are induced, in turn, either by an exogenous variation in the population's rate of growth, or by a technological innovation ${ }^{14}$. In such a case, these conditions will make capital scarcer in relation to labor, and thus raising its productivity.

Under the Neoclassical model, the capital's share in the production function is a key variable in the economic phenomenon of growth. Moreover, technical progress can neutralize capital's decreasing returns, allowing the economic system a sustained growth, although still keeping its exogenous character. In spite of its functionality, Solow's model still falls short of providing relevant explanations regarding the role played by the residual in the production function. Neoclassic theorists have searched for more

14 This is a neutral technical change in Harrod's sense (see Hall, 1994: 318). 
robust explanations in order to solve this unpleasant shortcoming, and among the several approaches proposed, endogenous models stand up by their formality and theoretical rigor. We shall next discuss the approach proposed by Paul Romer (1990).

\section{VII}

\section{NEOCLASSIC MODELS OF ENDOGENOUS GROWTH}

When Paul Romer published his pioneering paper in 1986, most scholars were still adherents of the Neoclassical School of balanced growth that assumed technical change as an exogenous factor (Amable, 1994; Scherer, 1999). But Romer's focus on increasing returns from human capital and knowledge challenged this perception and from 1986 onwards, knowledge is seen as one of the most important factors behind the sustained growth observed in the world economy during the last quarter of the past century (World Bank, 1998). Romer is now acknowledged as one of the main contributors to the "New Growth Theory», which aims at analyzing the endogenous role of knowledge and innovation on growth (Verspagen, 2005).

In a historical perspective endogenous growth models are not new, however. Kaldor (1957) and Arrow (1962) were among the first economic theorists to model the effects of learning on productivity, a few years later, Romer $(1986 ; 1990)$ and Lucas $(1988)$ began to model increasing returns in industrial output, focusing on human capital and knowledge's effects on productivity, and Romer's 1990 paper has become the standard reference for modeling endogenous technical change due to his formal treatment of knowledge. We now shall discuss this model more formally ${ }^{15}$.

Romer's approach is based on three elements: 1) technical change lies at the heart of Economic Growth; 2) technical change arises mostly because of intentional profit-seeking actions taken by entrepreneurs responding to market incentives; and 3) plans for transforming raw materials are different from other economic

15 The following discussion draws on the helpful interpretation of Romer's model provided by Hall, 1994, pp. 334-338. 
goods in the sense that, once created, no extra cost has to be incurred in using them repeatedly. Romer's model envisages a closed economy comprising three sectors: the research sector producing new technological knowledge in the form of designs for new producer durables, the intermediate goods sector which produces a range of producer durables and the final goods sector.

Technical knowledge, denoted $\Omega$, is measured in terms of the number of designs extant and each new design thus adds 1 to the current value of $\Omega$. Producer durables comprise a set $\{X\}=\left\{x_{1^{\prime}}, x_{2^{\prime}}\right.$ $\left.x_{3}, . ., x_{\Omega} \ldots x(¥)\right\}$,where $x$ is the output level and the numbers $i=1,2$, ... $¥$ label the goods. Within the set, $x\{\Omega+1) \ldots x(¥)$ take zero values until further new knowledge has been generated.

Final output $\mathrm{Q}$ is produced with a Cobb-Douglas production function, where $\mathrm{H}_{\mathrm{Q}}$ is human capital in producing $\mathrm{Q}$ :

$$
Q=H_{Q}^{a} \cdot L^{b} \sum_{i=1}^{\infty} x_{i}^{(1-a-b)}
$$

The aggregate labor force $\mathrm{L}$ is assumed constant, as is overall human capital, $\mathrm{H}$, of which $\mathrm{H}_{\mathrm{Q}}$ forms one part. In the former equation, designs are treated as discrete, indivisible objects but if problems of indivisibility and uncertainty are ignored, the index $i$ on $x$ can be treated as a continuous variable and the equation rewritten as:

$$
Q=H_{Q}^{a} \cdot L^{b} \int_{0}^{\infty} x(i)^{(1-a-b)} d i
$$

This function is homogeneous of degree one, allowing output in the final goods sector to be described in terms of a competitive firm (Berumen, 2005). In the intermediate goods sector, each producer durable is produced by a different firm which has bid successfully for the patent on the design for the good and thereafter manufactures it exclusively. Inputs into production are the design and capital goods converted from output sacrificed from consumption on a one-for-one basis. As a simplifying assumption, labor in- 
puts are set at zero. Given its monopoly position on design i, firm i faces a downward sloping demand curve along which x(i) units of $\mathrm{i}$ are at any point rented at a rate of $\mathrm{P}(\mathrm{i})$ per unit per period. Assuming no depreciation, the value of a unit of good $i$ is the Present Discounted Value (PDV) of the rental income stream it generates. In the final goods sector, the representative firm's profit, expressed in units of output, is:

$$
\left.\int_{0}^{\infty}\left[H_{Q}^{a} \cdot L^{b} \cdot x(i)^{(1-a-b)}-P(i) x(i] \dot{d}\right)\right] d i
$$

It is important to stress that the former equation must be differentiated with respect to $x(i)$ and set equal to zero to maximize this with respect to the quantities of each producer durable hired, which after rearrangement implies an (inverse) aggregate demand function for durables:

$$
P(i)=(1-a-b) \cdot H_{Q}^{a} \cdot L^{b} \cdot x(i)^{(-a-b)}
$$

For given values of $\mathrm{H}_{\mathrm{Q}}$ and $\mathrm{L}$, this is a constant elasticity demand curve for each i which the monopoly producer of each durable takes as given in setting its profit-maximizing output level and price. Each firm will already have invested in acquiring the design for the durable, but this is a sunk cost. In making its forward looking choices, it takes as given $\mathrm{H}_{\mathrm{Q}^{\prime}} \mathrm{L}$ and $r$ (the interest rate on loans measured in units of current output), to choose an output level $x$ to maximize at every date its revenue less variable cost. Its revenue, $\mathrm{P}(\mathrm{x}) \mathrm{x}$ is its flow of rental from final goods producers and from the former equation equal to,

$$
P(x) x=(1-a-b) H_{Q}^{a} \cdot L^{b} \cdot x^{(-a-b)}
$$

To make each unit of the durable, J units of output are sacrificed from consumption. Variable costs thus total $r \mathrm{~J} \mathrm{x}$, implying a constant marginal cost of $r \mathrm{~J}$. Each monopolist's price, $\mathrm{RJ} /(1-\mathrm{a}-\mathrm{b})$ is a mark-up over marginal cost determined by the elasticity of de- 
mand. Total capital $\mathrm{K}$, the aggregate of producer durables in use, is found by multiplying the quantities of each type of capital employed in production by the output foregone in producing each unit.

$$
K=J \int_{i=1}^{\infty} x(i)
$$

The aggregate $\mathrm{K}$ changes according to the accounting rule (where $\mathrm{C}(\mathrm{t})$ is consumption):

$$
\frac{\mathbb{K}(t)}{d K}=Q(t)-C(t)
$$

Research sector output comprises increases in technological knowledge, $\mathrm{d} \Omega / \mathrm{dt}$, and is generated with inputs of existing knowledge and human capital located in the sector. If researcher $m$ has an amount of human capital $\mathrm{H}_{\mathrm{m}}$ and access to a portion $\Omega_{\mathrm{m}}$ of the total stock of knowledge implicit in previous designs, the production rate of new designs by $m$ will be $\mathrm{zH}_{\mathrm{m}} \Omega_{\mathrm{m}^{\prime}}$, where $\mathrm{z}$ is a productivity parameter. All researchers are assumed to have free access to all knowledge $(\Omega)$ at any given time. Thus we observe that $H_{\Omega}$ is total human capital in research:

$$
\frac{d \Omega}{d}=z \cdot H_{\Omega} \cdot \Omega
$$

Implicit in this formulation are two further and crucial assumptions: 1) devoting more human capital to research leads to an increase in the rate of production of new designs, since $[\mathrm{d}(\mathrm{d} \Omega / \mathrm{dt}) /$ $\left.\mathrm{dH}_{\Omega}\right]=\mathrm{z} \Omega>0 ; 2$ ) adding to the stock of knowledge, $\Omega$, yields growth in the marginal productivity of human capital in research at a rate constant and proportional to $\Omega$ itself. This is so because the marginal productivity of $\mathrm{H}_{\Omega^{\prime}} \mathrm{d} \Omega / \mathrm{dH}_{\Omega^{\prime}}$ is rising at the rate $(\mathrm{d} /$ 
$\mathrm{dt})\left(\mathrm{d} \Omega / \mathrm{dH}_{\Omega}\right)$, which is $\mathrm{z} \Omega^{16}$. On the other hand, the market for designs is competitive, so the price for designs is bidden up by potential users until it is equal to the present value of the net revenue that a monopolist expects to extract from it. Then, at every point in time the excess of revenue over marginal cost must be just sufficient to cover the interest cost on the initial investment in the design, that is:

$$
\Pi(t)=r(t) P_{\Omega}
$$

In the former equation, $\Pi(\mathrm{t})$ is monopolist's profit, and $\mathrm{P}_{\Omega}$ the cost of producing a new design. This condition determines whether a new design will be produced or not, i.e. depending on whether its costs will be covered or not. Finally, consumers are endowed with fixed quantities of labor and human capital, own the existing durable goods producing firms and an implication of their intertemporal maximizing behavior used in the analysis is that consumption grows at the rate $(r-d) / s$, where $d$ is the subjective discount rate and $s$ is the intertemporal rate of substitution (Berumen and Palacios Sommer, 2007). The model produces as a result, if $\Omega$ is fixed, the following equations:

$$
\begin{gathered}
Q=\left(H_{Q} \Omega\right)^{a} \cdot(L \cdot \Omega)^{b} \cdot K^{(1-a-b)} \cdot J^{(a+b-1)} \\
=H_{Q}^{a} \cdot L^{b} \cdot \Omega \cdot X_{\#}^{(1-a-b)}
\end{gathered}
$$

where the symmetry of the model implies that all existing durables will be supplied at the same level, $x_{\text {\#f }}$ The model behaves like the Neoclassical Growth model with labor —and human capital-augmenting technical change. If $\Omega$ grows at an exogenously specified exponential rate, the economy converges on a balanced growth path on which the rate of supply of durables and the ratio

${ }^{16}$ Hall (1994: 337) points out that this rising productivity in research reflects beneficial spillovers, which also has the effect of preventing the returns to human capital from falling and hence prevents migration from research to manufacturing as $\Omega$ grows. 
of $\mathrm{K}$ to $\Omega$ would be constant. Since both $\mathrm{K}$ and $\Omega$ are growing, human capital wage in final output will also rise.

To identify the characteristics of the model, in this case solve the equilibrium conditions along the balanced growth path, it can be shown that the cost of producing a new design $\mathrm{P}_{\Omega}$ is:

$$
P_{\Omega}=\left[\frac{(a+b)}{r} \rrbracket 1-a-b\right) H_{Q}^{a} \cdot L^{b} \cdot x_{\#}(1-a-b)
$$

In equilibrium, the return on human capital in both research and manufacturing $(\mathrm{wH})$ must be the same as the marginal productivity of human capital in each sector otherwise it would pay some units of human capital to relocate (Berumen and Pérez-Megino, 2015; Berumen, 2016). The wage in the research sector is simply all the income generated there $\left(\mathrm{P}_{\Omega^{\prime}} \mathrm{z} \Omega\right)$, and to equalize returns to human capital in both sectors, $\mathrm{H}_{\mathrm{Q}}=\mathrm{H}-\mathrm{H}_{\Omega}$ must be chosen so that $\mathrm{wH}$ and $\mathrm{P}_{\Omega^{\prime}} \mathrm{z} \Omega$ both equal the marginal product of human capital in the final goods sector, so:

$$
a \cdot H_{Q}^{(a-1)} \cdot L^{b} \cdot \Omega \cdot x_{\#}^{(1-a-b)}
$$

From the former equation, one can observe that the marginal product of $\mathrm{H}_{\mathrm{Q}}$ grows in proportion to $\Omega$. Therefore, rising productivity of human capital in the research sector is essential to prevent human capital from migrating to manufacturing. This in turn is vital to ensure that the research engine of growth is maintained and that sustained, non-slowing growth can persist, as the following term implies:

$$
\left.H_{Q}=(1 / z) r\{\mathrm{a} /[1-a-b)(a+b)]\right\}
$$

Recalling that $\Omega$ grows at the exponential rate $\mathrm{zH}_{\Omega}$ when $\mathrm{H}_{\mathrm{Q}}=$ $\mathrm{H}-\mathrm{H}_{\Omega}$ is fixed. If $r$ is fixed, $\mathrm{x}_{\#}$ is also fixed (an implication of monopoly pricing). Besides, $\mathrm{Q}$ grows at the same rate as $\Omega$ if $\mathrm{L}, \mathrm{H}_{\mathrm{Q}}$ and $\mathrm{x}_{\#}$ are fixed. If $\mathrm{x}_{\#}$ is fixed, $\mathrm{K}$ and $\Omega$ grow at the same rate, since total capital usage is $\Omega x_{\#}$. Let $g$ stand for the common growth rate of $\Omega$, $\mathrm{K}$ and $\mathrm{Q}$, Then: 


$$
g=(d Q / d t) / Q=(d K / d t) / K=(d \Omega / d t) / \Omega=z H_{\Omega}
$$
plies:

which, together with $\left.H_{Q}=(1 / z) r\{\mathrm{a} /[1-a-b)(a+b)]\right\}$ im-

$$
g=z H_{\Omega}=z H-[a /(1-a-b)(a+b)] r
$$

Importantly, this equation predicts that, along balanced growth paths, countries with greater stocks of human capital $(\mathrm{H})$ will experience faster rates of Economic Growth. It also suggests that Economic Growth will be faster, the greater is the productivity of human capital employed in research $\left(\mathrm{H}_{\Omega}\right)$. Hence, Romer's model is useful to understand the role that human capital plays in productivity, as well as to understand why growth rates differ.

An important characteristic of endogenous growth models is that knowledge arising from any particular productive process is prone to get a widespread diffusion and become a sort of "public good $^{17} \gg$. Therefore, once knowledge is amply available to society it becomes a non-rival, non-exclusive good (OECD, 1992: 51).

Given that the stock of new knowledge tends to grow from producers' initial endowments (due to learning effects), it is necessary to protect their intellectual rights in order for them to guarantee their investment returns before this new knowledge becomes «public knowledge» (Verspagen, 2005).

As Hall (1994) points out, Romer's model is also useful to explain interest rate's role in growth. Interestingly, his approach relates human capital formation to interest rate through investments in education. Then, a higher interest rate implies a higher opportunity cost of investing in education to acquire human capital and hence tends to discourage investment in it.

In spite of these important contributions, Romer's approach to Economic Growth is not exempted of criticisms. One of these critiques is concerned with the practical measurement of endogenous

${ }_{17}$ Romer (1990: S74) argues that public goods are both non-rival and non-excludable. He also points out that because public goods are non-excludable, they cannot be privately provided or traded in markets. 
growth, as pointed out by Stern (1991: 127), it may be difficult to identify a knowledge-producing sector in real economies. Besides, endogenous growth models still exhibit limitations to explain the mechanism under which knowledge determines innovation. For example, Verspagen (2005) points out that growth models based on the Neoclassical approach wrongly assume growth as a stable and orderly process, which is something that real world experience clearly denies. Hence, we shall next consider the Schumpeterian approach to Economic Growth (Berumen, 2010).

\section{VIII \\ SCHUMPETERIAN MODELS OF ECONOMIC GROWTH}

A quick look at the history of economic development tells us that Adam Smith was the first economist in noting how technology spurred workers' productivity. In describing technical innovations in eighteenth century England, Smith saw how new technology became embedded in faster and more efficient machines, which were the result of the necessities presented by the increasing division of labor in the British manufacturing (Salerno, 1999; Scherer, 1999: 8-10).

A hundred years later, Karl Marx stressed the social character of technical change by noting that capitalism had succeeded in creating the necessary incentives to capital accumulation by means of taking advantage of innovations in the production of merchandises (Rosenberg, 1982: 34-51; Aarons, 2009).

More recently, Schumpeter (1912; 1950), in thinking about growth, introduces two fundamental concepts into economic theory. First, innovation is the main factor behind economic development because it stimulates growth though material prosperity ${ }^{18}$. Second, innovation does not come out of nothing, it asks for entre-

${ }^{18}$ Schumpeter argues that economic development depends on the entrepreneurs' ability to recombine production, so he distinguishes five different cases: 1) the introduction of new products, 2) the introduction of new industrial processes, 3) the exploitation of new markets, 4) the conquest of new sources for raw materials, and 5) new forms of industrial organization (Schumpeter, 1950: 83). 
preneurs with a strong commitment to exploit market opportunities. That is, innovative entrepreneurs are prone to establish new directions in economic activity. In Schumpeter's view, this process of "creative destruction» is the essential fact about capitalism (Schumpeter, 1950: 81-86).

Schumpeter's insight into innovation helped to create an important economic school that highlights the punctuated, and sometimes turbulent, character of Economic Growth (McCaffrey, 2009). This school has been dubbed as Schumpeterian (Fagerberg, 1994; Nelson and Winter, 1982; Scherer, 1999; Verspagen, 2005).

At the core of the Schumpeterian approach is a redefinition of technological change itself. Contrary to the Neoclassical view which regards technological change as either the choice of one technique to replace another from an existing set, or a change in the productivity of one or more of the given techniques available, Schumpeterian economists define the process of technological change as the search for new and hitherto unknown techniques to add to the known set. Thus, Economic Growth is dependent on technological innovation.

Economic models based on this approach emphasize three elements in the social context that determine growth: 1) the institutional milieu in which technical change takes place and prosper; 2 ) the role of demand in growth; and 3) the existence of organizational and industrial processes which are heavily dependent on agents' «bounded rationality ${ }^{19} »$.

For some Schumpeterian scholars, the rate of Economic Growth in the long-term should be compatible with the equilibrium in the balance of payments. This assumption introduces a Keynesian component into the analysis by linking the income elasticity of demand for exports and imports as a result of the widespread mobility of international capitals for innovation investments (Mises, et al., 1978).

${ }^{19}$ In this respect, it is worth emphasizing that the assumption that firms maximize profits may no longer be meaningful in a complex decision space with an objective function in unbounded time. Firms are assumed by evolutionary economists to be profit seeking rather than profit maximizing (see, for example, Nelson and Winter, 1982: 24-30). 
In this perspective, Bart Verspagen (1993) proposes a simple approach to encompass trading interdependencies between economies that can help modeling the growth path between developed (North) and developing countries (South). To this end, Verspagen suggests that technical change in the South is a non-linear function of its initial condition in the technological gap.

The existence of this gap may encourage innovation in the South to the extent that a developing country may be capable of (successfully) imitating proven technologies. Nonetheless, if this gap is too large (larger than a certain threshold), technological diffusion becomes harder to achieve as the imitative capabilities of the South tend to diminish if the technological gap widens. For a given initial state, the imitative intensity will depend on internal learning capabilities. This implies that developing countries should have an institutional base to identify, adapt and improve the imported technology. Therefore, Verspagen sees technology acting directly and indirectly on Economic Growth (Verspagen, 1993: 127). The direct effect is linked to the enhancement of the stock of technological knowledge that can be harnessed by firms. The indirect effect is associated with rising exports, that is (Berumen and Pérez-Megino, 2015):

$$
y_{i}=\alpha t_{i}+\varepsilon x_{i} \quad i=s, n
$$

where $y_{i}$ is the rate of growth in output, $t_{i}$ is the rate of growth in technological capabilities and $x_{i}$ is the rate of growth in exports for country $i$. This equation states that the rate of growth for country $i$ depends on the rate of technical change and the increase in exports. The rate of growth in exports for a given country is a function of its achieved level of technological capabilities (i.e., its international competitiveness) as well as of the rate of growth of the world economy (z), namely,

$$
x_{s}=\eta \cdot L\left(\frac{T_{s}}{T_{n}}\right)+z
$$




$$
x_{n}=\eta \cdot L\left(\frac{T_{n}}{T_{s}}\right)+z
$$

If $T_{n}>T_{s^{\prime}}$ then $L\left(T_{n} / T_{s}\right)=G$, and the technological gap will be positive; which means that exports in the North will grow at a higher rate than the international economy. The rate of technical progress in the North, $t_{n^{\prime}}$ is a function of its autonomous rate of innovation $\left(\beta_{n}\right)$ and of the technological learning associated with productive learning (i.e., learning by doing). This kind of learning is called the "Verdoorn effect», which is represented by the term $\lambda \mathrm{y}_{\mathrm{n}}$ in the following equation:

$$
t_{n}=\beta_{n}+\lambda y_{n}
$$

A distinctive feature of this model is how technical change in the South $\left(\mathrm{t}_{\mathrm{s}}\right)$ evolves,

$$
t_{s}=\beta_{s}+\lambda y_{s}+a \cdot G e^{-G / \delta}
$$

Where $\mathrm{aGe}^{-\mathrm{G} / \delta}$ indicates the international diffusion of technology, and $\mathrm{G}=\mathrm{L}\left(\mathrm{T}_{\mathrm{n}} / \mathrm{T}_{\mathrm{s}}\right)$ is the technological gap ${ }^{20}$. This equation demonstrates the existence of a non-linear relationship between the technological gap $(\mathrm{G})$ and the rate of technical change in the South. Technology gap may stimulate the international diffusion of technology if developing countries take advantage of the imitation possibilities. Apart from the level of the technological gap, this stimulus also depends on the parameter $\delta$, which represents a measure of the «intrinsic learning capability» of the South. The maximum level in the rate of technology diffusion toward the South is reached when $G=\delta$. Any increase in this critical value diminishes technology diffusion due to the widening of the technological gap (Verspagen, 1993: 133).

Then, the larger the value of $\delta$, the stronger the international diffusion of technical progress, for any given level of the technology

${ }^{20}$ It is worth stressing that in Verspagen' model, the Verdoorn effect tends to create dynamic and positive incentives for the country with the fastest rate of growth. 
gap G. The learning capability of the South $(\delta)$ depends on its institutional and productive frameworks, especially in relation to the institutions devoted to the development of science and technology (Idem: 134).

According to this approach, if the intrinsic learning capability in the South is very limited, international diffusion of technology will be deficient. On the other hand, the very existence of the technological gap draws an asymmetric competitive line between North and South. The weaker competitive position of the South generates a lesser dynamism in demand and fewer stimuli to growth (Todaro and Smith, 2005). The global result on Economic Growth will depend on both the rate and direction of the competitive effect and the technology diffusion effect.

Even though the findings derived from Verspagen's model look robust, one should be very cautious in assuming that the existence of a technological gap between North and South can instantly spur technology diffusion (see, for example, Fagerberg, 1994: 1150; Scherer, 1999: 35-36). However, growth convergence between North and South may well be stimulated by the existence of appropriate institutional and technological capabilities in the South. Yet, if the technological gap keeps on growing due to differences in productivity between North and South, a growth convergence cannot be guaranteed. In such a case, convergence will be possible only if the South accelerates its innovation effort (Archibugi and Pietrobelli, 2003).

IX

\section{CONCLUSION}

Since 1945, the world economy has attested an incessant appearance of new and better technologies that have enhanced people's welfare. This impressive technological progress has been the result of the knowledge accumulated by the society through the years. And those nations that have learnt how to take advantage of it have achieved impressive rates of Economic Growth as well. Since that time, economists have painstakingly searched for useful explanations to this phenomenon. In this search, they have produced seve- 
ral approaches and theories, from which those concerned with the role that scientific knowledge plays in Economic Growth stand out.

Cumulative scientific knowledge can be found in several forms, such as new and better products, faster and more efficient processes, new and cheaper materials and components, cleaner and more efficient sources of energy, and so on. All these features of Economic Growth have been summarized in the term «knowledgebased economy", showing us that growth no longer depends exclusively on large endowments of land, raw materials, or investments in traditional capital or unskilled labor, but on an efficient administration of the input «knowledge».

In this article we identified and exposed the most important theories dealing with Economic Growth. Our principal aim was to stress the importance of human capital in growth by linking the effects of cumulative learning and knowledge on technical change and innovation. One should be borne in mind, however, that the dynamics of knowledge creation, exchange and diffusion remains surprisingly poorly understood, even for the most advantaged schools of economic thought. Yet, this should represent a challenge rather than a weakness for the economists interested in studying this fascinating process.

\section{REFERENCES}

Aarons, E. (2009), Hayek versus Marx, London, Routledge (Taylor and Francis).

Aghion, P. \& HowitT, P. (1998). Endogenous Growth Theory, Cambridge, USA: The MIT Press.

Amable, B. (1994). Endogenous Growth Theory, Convergenece and Divergence. In G. S. Editor, \& L. S. Editor (Eds.), The Economics of Growth and Technical Change (pp. 20-44). Aldershot, UK: Edward Elgar.

Archibugi, D. \& Pietrobelli, C. (2003). The Globalization of Technology and its Implications for Developing Countries: Windows of Opportunity or Further Burden?. Technological Forecasting and Social Change, 70, 861-883. 
Arrow, K. J. (1962). The Economic Implications of Learning by Doing. Review of Economic Studies, 29, 155-173.

Berumen, S. A. (2016). Did Income Inequality Benefit or Hinder Economic Growth in Europe?, Journal of Social, Political, and Economic Studies, Forthcoming.

- (2008). Una Aproximación a la Construcción del Pensamiento Neoschumpeteriano: Más allá del Debate entre Ortodoxos y Heterodoxos. Información Comercial Española (ICE), 845, 135-148.

- (2005). An Approach to Local and Regional Competitiveness. Cuadernos de Administración, 18 (29), 13-32.

— \& Merritt, H. (2010). An Approach to the Principles of the Economics of Innovation and Growth, in C. Nardi Spiller, Issues in Economic Thought, Nova Publishers, Nueva York, 203-224.

— \& P. Pérez-Megino, L. (2015). El papel de la desigualdad de ingresos en el proceso de crecimiento en Europa, Instituto Universitario de Análisis Económico y Social. Working Paper Series. WP09/15.

— \& Palacios Sommer, O. A. (2007). Los principios de la teoría de la evolución biológica y su utilidad para la administración de empresas. Revista Contaduría y Administración, 223, 137-154.

Boulding, K. E. (1966). The Economics of Knowledge and The Knowledge of Economics. American Economic Revieww, 56, 1-13.

Costabile, L. \& Rowthorn, R. E. (1985). Malthus's Theory of Wages and Growth. Economic Journal, 95, 418-437.

FAGERBERG, J. (1994). Technology and International Differences in Growth Rates. Journal of Economic Literature, 32, 1147-1175.

Gregersen, B. \& Johnson, B. (2000). How Do Innovations Affect Economic Growth? Some Different Approaches in Economics. In C. E. Editor \& M. M. Editor (Eds.), Systems of Innovation: Growth, Competitiveness and Employment, (pp. 326-353). Cheltenham, UK: Edward Elgar.

GRIMALDI, R. \& ToRRISI, S. (2001). Codified-tacit and General-specific Knowledge in the Division of Labour Among Firms: A Study of the Software Industry. Research Policy, 30, 1425-1442.

Hahn, F. H. \& Matthews, R. C. O. (1964). The Theory of Economic Growth: A Survey. Economic Journal, 74, 779-902.

Hall, P. (1994). Innovation, Economics and Evolution, London: Harvester Wheatsheaf. 
HenG, T. M., Chin, T. H., \& Choо, A. (2002). Mapping Singapore's Knowledge-Based Economy. Economic Survey of Singapore, 2002, 56-75.

Hoselitz, B. F. (1952), «Entrepreneurship and Economic Growth,», American Journal of Economics and Sociology, 12(1), 97-110.

Hoselitz, B. F. (1963), «Main Concepts in the Analysis of the Social Implications of Technical Change», in Bert F. Hoselitz and Wilbert E. Moore (eds.), Industrialization and Society. UNESCO-Mouton, 11-31.

HÜlSMANN, J.G (1999), «Entrepreneurship and Economic Growth:

Comment on Holcombe», The Quarterly Journal of Austrian Economics, 2(2), 63-65.

Jovanovic, B. (2001). Economic Growth: Theory. In N. J. S. Editor, \& P. B. B. Editor (Eds.), International Encyclopedia of the Social and Behavioral Sciences (pp. 4098-4101). Amsterdam: Elsevier.

KaLdoR, N. (1957). A Model of Economic Growth. Economic Journal, 67, 591-624.

KHAN, M. (2001). Investment in Knowledge. STI Review, 27, 19-48.

Low, M. B. \& Abrahamson, E. (1997). Movements, Bandwagons, and Clones: Industry Evolution and the Entrepreneurial Process. Journal of Business Venturing, 12, 435-457.

LuCAS, R. E. (1988). On the Mechanics of Economic Development. Journal of Monetary Economics, 22, 3-42.

LuNDVALL, B.-A. (1992). National Systems of Innovation: Introduction. In B.-A. L. Editor (Ed.), National Systems of Innovation (pp. 1-19). London: Pinter.

Malthus, T. R. (1803[1999]). An Essay on the Principle of Population. Oxford: Oxford University Press [Oxford World's Classics 1999 edition].

Mankiw, N. G. (2002). Macroeconomics. New York: Worth Publishers. MCCAFFrEY, M. (2009), «Entrepreneurship, Economic Evolution, and the End of Capitalism: Reconsidering Schumpeter's Thesis», The Quarterly Journal of Austrian Economics, 12(4), 3-21.

Mises L.; HAberler, G.; Rothbard, M.; and HAYEK, F. ([1978] 1996), The Austrian Theory of the Trade Cycle and Other Essays. Auburn, Ala.: Ludwig von Mises Institute.

Mowery, D. C. \& OxLey, J. E. (1997). Inward Technology Transfer and Competitiveness: The Role of National Innovation Systems. 
In D. A. Editor, \& J. M. Editor (Eds.), Technology Globalisation and Economic Performance (pp. 138-171). Cambridge, UK: Cambridge University Press.

Nelson, R. R. (1993). National Innovation Systems: A Comparative Analysis. New York: Oxford University Press.

— \& Winter, S. G. (1982). An Evolutionary Theory of Economic Change. Cambridge, USA: Harvard University Press.

NonaKa, I. \& TAKeUChI, H. (1995). The Knowledge-Creating Company.

New York: Oxford University Press.

OECD (1996). The Knowledge-Based Economy. Paris: OECD.

OECD (1998). Technology, Productivity and Job Creation: Best Policy Practices. Paris: OECD.

OECD (2000a). Korea and the Knowledge-based Economy: Making the Transition. Paris: OECD.

OECD (2000b). Science, Technology and Industry Outlook 2000. Paris: OECD.

OECD (2014). Science, Technology and Industry Outlook 2014. Paris: OECD.

OECD (2014). Innovation and Growth: Rationale for an Innovation Strategy. Paris: OECD.

PArkin, M. (2003). Economics. Boston: Addison-Wesley.

Pérez-Megino, L. P. \& Berumen, S. A. (2015). Globalization and Inequalities in Developed Economies: Kuznets was not Right, Neumann Business Review, 1 (2). Forthcoming.

RoDrIK, D. (2007). One Economics, Many Recipes: Globalization, Institutions, and Economic Growth, Princeton University Press, New Jersey. Rogers, E. M. (2001). Theory of Innovation. In N. J. S. Editor, \& P. B. B. Editor (Eds.), International Encyclopedia of the Social and Behavioral Sciences (pp. 7540-7543). Oxford: Elsevier.

ROMER, P. M. (1986). Increasing Returns and Long-Run Growth. Journal of Political Economy, 94, 1002-1037.

- (1990). Endogenous Technological Change. Journal of Political Economy, 98, s71-s102.

RosenBerg, N. (1982). Inside the Black Box: Technology and Economics. New York: Cambridge University Press.

SAlerno, J. T. (1999), «The Place of Mises's Human Action in the Development of Modern Economic Thought», The Quarterly Journal of Austrian Economics, 2(1), 35-65. 
Samuelson, P. A. \& Nordhaus, W. D. (2002). Economics. New York: McGraw-Hill.

Scherer, F. M. (1999). New Perspectives on Economic Growth and Technological Innovation. Washington: Brookings Institution Press.

SCHUMPETER, J. A. (1912). Theorie der Wirtschftlichen Entwicklung. Munich: Verlag Dunker und Humbolt.

- (1950). Capitalism, Socialism and Democracy. New York: Harper \& Row.

Shapiro, C. \& VArian, H. R. (1999). Information Rules: A Strategic Guide to the Network Economy. Boston: Harvard Business School Press.

SoEte, L. (2001). The New Economy: A European Perspective. In D. A. Editor, \& B.-A. L. Editor (Eds.), The Globalizing Learning Economy, (pp. 21-44). Oxford: Oxford University Press.

Solow, R. M. (1956). A Contribution to the Theory of Economic Growth. Quarterly Journal of Economics, 70, 65-94.

Solow, R. M. (1957). Technical Change and the Aggregate Production Function. Review of Economics and Statistics, 39, 312-320.

SteEdman, I. (2001). On 'Measuring' Knowledge in New (Endogenous) Growth Theory. Conference Paper, Pisa, Italy: The Growth Theory Conference. 5-7 October 2001.

Stern, N. (1991). The Determinants of Growth. Economic Journal, $101,122-133$.

Tassey, G. (2004). Policy Issues for R\&D Investment in a Knowledge-Based Economy. Journal of Technology Transfer, 29, 153-185.

Todaro, M. \& SMith, S. (2005). Economic Development, Addison Wesley.

Verspagen, B. (1993). Uneven Growth Between Interdependent Economies. Aldershot, UK: Avebury.

Verspagen, B. (2005). Innovation and Economic Growth. In J. F. Editor, D. C. M. Editor, \& R. R. N. Editor (Eds.), The Oxford Handbook of Innovation (pp. 487-513). Oxford: Oxford University Press.

WorLd BANK (1998). World Development Report 1998: Knowledge for Development. Washington: World Bank. 
